\title{
CHRONOLOGY OF NEOLITHIC-EARLY METAL AGE SITES AT THE OKHTA RIVER MOUTH (SAINT PETERSBURG, RUSSIA)
}

\author{
M Kulkova ${ }^{1,2} \cdot$ T Gusentzova $^{3} \cdot$ E Nesterov $^{1} \cdot$ P Sorokin $^{3} \cdot$ T Sapelko $^{4}$
}

\begin{abstract}
The unique archaeological monument of Okhta 1 (Neolithic-Early Metal Age) was excavated in 2008 in central Saint Petersburg (Russia). Radiocarbon and wiggle-match dating of organic materials and artifacts (charcoal wood samples and ceramic food crusts) from lithological and cultural layers helped to determine the main stages of cultural-historical processes and paleogeographical events in the coastal zone of the Baltic Sea bay during the Holocene. Humans occupied the Okhta Cape from 4200-3600 cal BC, after the Littorina Sea regression. Prehistoric people of the Middle-Late Neolithic, identified by their characteristic Pit Combed Ware ceramics, used this territory for fishing and hunting. The wood pile constructions used for fishing in $3500 \mathrm{cal} \mathrm{BC}$ were built on the coast and in river channels. From 3200-3000 cal BC, settlements and burials appeared of the Late Neolithic-Early Metal Age. The strategic geographical position of this territory was favorable for trade activity, fishing, and hunting, and shaped important interactions for different cultural groups.
\end{abstract}

\section{INTRODUCTION}

Saint Petersburg and the Leningradskaya district are strategically located between northwestern Russia, Finland, and the Baltic countries, and therefore play a key role in understanding the region's cultural-historical processes in prehistory. The early human migrations in the southeastern Baltic area occurred during drastic environmental changes, the most important of which were related to the postglacial evolution of the Gulf of Finland, Ladoga Lake, and the hydrological network linked to these basins (Dolukhanov et al. 2007). Water-level fluctuations resulting from the isostatic land uplift caused a sea regression/transgression in this area. The river beds and coastal lines of water reservoirs changed and likely influenced the choice of human habitation locations. Geological data regarding terrace formations are useful for the chronology of ancient settlements (Saksa 2006). The middle Holocene is the most important period for this region due to the intensive land occupation, the increase in population, and the appearance of immigrants from neighboring territories (see Gerasimov et al. 2003). As a result, numerous archaeological monuments of the Neolithic-Early Metal Age have been excavated on the Karelian Isthmus (Figure 1).

The first archaeological site of the Stone and Early Metal ages was found in central Saint Petersburg in 2008 (Figure 2). This is the Okhta 1 settlement, which is situated on a cape at the mouth of the Okhta and Neva rivers. This site was discovered during archaeological efforts to protect the fortresses of 13 th century Landskrona and 17th century Nienshanz. Cultural artifacts were excavated in a $>10,000 \mathrm{~m}^{2}$ area in central Saint Petersburg, while on the cape an area of $6700 \mathrm{~m}^{2}$ was excavated (Figure 2). Okhta 1 is a prototypical site for the Neolithic-Early Metal ages in the region. The site's many diverse artifacts and their preservation provide outstanding examples to study the chronology of cultural-historical processes and their connection with paleoenvironmental changes.

\section{DESCRIPTIVE BACKGROUND AND PALEOGEOGRAPHICAL REVIEW}

The area under study is situated in northwestern Russia between the Gulf of Finland and Lake Ladoga. The environmental changes at about 7200 cal BC (8000 BP) mark the beginning of the Atlantic period, the time of the Holocene optimum (Rõuk 1995). As a result of the Littorina trans-

\footnotetext{
${ }^{1}$ Herzen State Pedagogical University of Russia, Saint Petersburg, Russia.

${ }^{2}$ Corresponding author. Email: kulkova@mail.ru.

${ }^{3}$ Research Institute "Heritage," Saint Petersburg, Russia.

${ }^{4}$ Institute of Limnology RSA, Saint Petersburg, Russia.
}

(C) 2012 by the Arizona Board of Regents on behalf of the University of Arizona Proceedings of the 6th International Radiocarbon and Archaeology Symposium, edited by E Boaretto and N R Rebollo Franco RADIOCARBON, Vol 54, Nr 3-4, 2012, p 1049-1063 


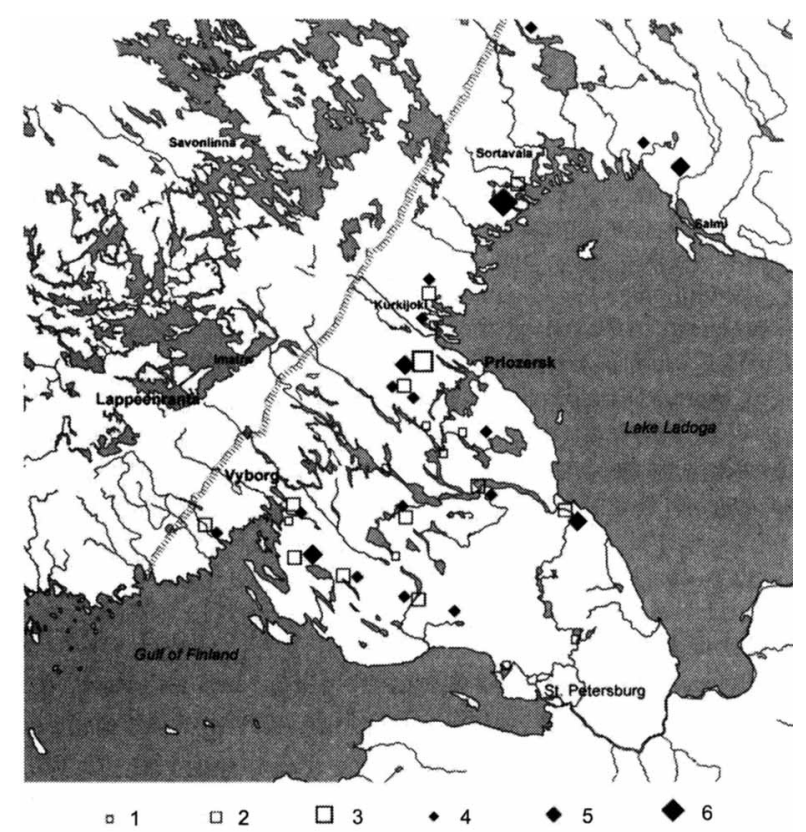

Figure 1 Location of Neolithic sites (after Huurre 2003) with Early Comb Ware (1-3) and Pit Comb Ware (4-6) ceramics: 1, 4- one site; 2, 5 - two sites; 3,6 - several sites.
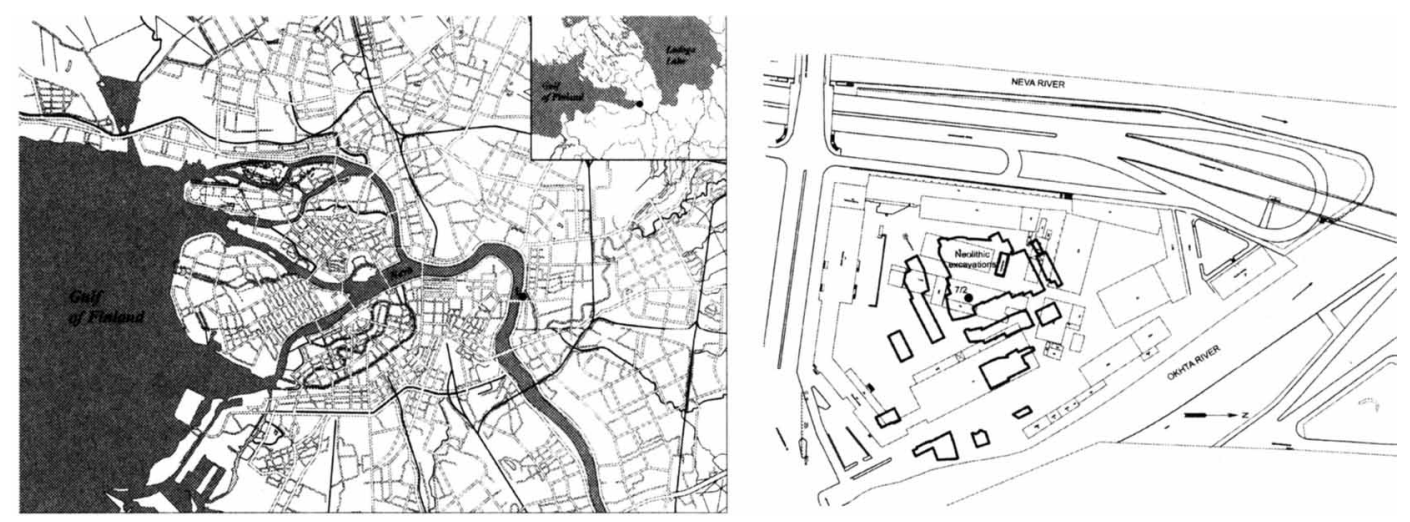

Figure 2 Map of Saint Petersburg and the location of Neolithic-Early Metal Age excavations (2008-2009) on the cape at the mouth of the Okhta and Neva rivers.

gression, with a maximum of $6200 \mathrm{cal} \mathrm{BC}(7300 \mathrm{BP})$ near the modern Gulf of Finland coast, shallow zones with numerous islands and deep bays were formed. The fluctuations in ocean water level became stable just after 4800 cal BC (6000 BP) (Miettinen 2002). Due to postglacial isostatic uplift and sea regression, the shallow coastal zones were drained gradually. These changes created favorable living conditions for the site's ancient inhabitants. From the end of $5000 \mathrm{cal}$ BC to the beginning of 4000 cal BC, Baltic Pit-Combed Ware ceramics began to spread (Pesonen 1999; Lang and Kriiska 2001)-evidence of transregional exchange and intensive interactions. Also at this time, Baltic ambers appeared (Loze 1985; Ots 2003; Zhulnikov 2008) and the amount of tools from imported flints increased (Galibin and Timofeev 1993; Kriiska and Tvauri 2007), further evidence 
of favorable and extensive trade in the area. According to Saksa (2006), the Karelian Isthmus, northern Ladoga Basin (Karelian region), and eastern Finland were the dispersal area for ceramics with pits and comb imprint ornamentation typical also for the regions of the Upper Volga, the Oka, the Valdai Plateau, and Karelia. This region is delimited by the southern shore of the White Sea in the north and by the Severnaya (North) Dvina in the east. Moreover, the areas of the Karelian Isthmus, Karelia, the eastern Baltic region, Leningrad Province, and the regions of Finland situated to the west of the Vuoksi River were dispersal areas for the western tradition of Pit-Comb Ware ceramics. In addition, southern Ladoga and the northern Leningrad Province comprise the dispersal region of Narva ceramics (Gurina 1967; Timofeev 1985; Huurre 2000, 2003; Saksa 2001).

The emergence of typical Pit-Comb Ware ceramics ("Comb Ware" in other terminology) in Finland and the eastern Baltic region is linked with the migration of a new population to the area as well as to the cultural impact from the Karelian Ladoga region and the Karelian Isthmus where early PitComb Ware ceramics were common (Huurre 2000, 2003; Saksa 2001; Gerasimov and Subetto 2009). Some scholars argue that this tradition arrived from the Upper Volga region (e.g. Bader 1972). Typical Comb Ware ceramics were replaced by Late Comb Ware ceramics around 3600 BC. Ceramics with an admixture of asbestos emerged in eastern Finland and the Karelia regions near Lake Ladoga and partially in Leningrad Province at that period. The amount of imported flint decreased, while the number of implements made of local slate and quartz increased (Saksa 2006).

Around $3000 \mathrm{cal} \mathrm{BC}$, at the transition of the Stone Age to the Early Metal Age, significant climatic changes were determined in the Gulf of Finland area. These changes influenced sociocultural structures of the ancient inhabitants. The area under study mostly developed within the culture of asbestos ceramics (eastern Finland and northern Karelia including the northern Ladoga basin) and Late Comb Ware ceramics (Karelian Isthmus and southern Karelia). As late as 1300 BC, the area was strongly influenced by "textile imprint" ceramic culture, which was widespread in the Upper Volga and the Oka regions, including the Karelian Isthmus, Karelia, and eastern regions of Finland (Meinander 1982; Huurre 2000, 2003; Saksa 2001; Lavento et al. 2002). However, in the inner regions of Finland, including Savo, the asbestos ceramic tradition continued. Asbestos ceramics along with "textile" pottery were also used in the northern Ladoga basin and in northern Karelia. Already in the Early Metal Age, asbestos ceramics were dispersed throughout northern Fennoscandia and the Kola Peninsula (Gurina 1967; Carpelan 1979; Huurre 2000; Lavento 2001; Saksa 2001).

\section{CULTURAL LAYER CHARACTERISTICS AT OKHTA 1}

Neolithic-Early Metal Age cultural layers at the mouth of the Okhta and Neva rivers were covered by $1-1.5 \mathrm{~m}$ of aleurite-sand deposits and buried by soil of Medieval age. The stratigraphy of the cultural layers, the numerous wooden construction remains, and the composition of finds indicate repeated occupations in this territory during the Neolithic-Early Metal Age. In 2009 at the Okhta 1 site, detailed investigations were conducted on lithological and cultural deposits from a cross-section of the northwestern wall of excavation 7/2 (Kulkova et al. 2010). Radiocarbon dating was conducted along with archaeological, lithological, and mineralogical-geochemical studies, as well as analyses of grain size, pollen, and diatoms.

The cultural layer consists of 2 main horizons of aleurite with thin sandy layers. The layer of coarsegrained sand of alluvial origin forms the boundary between the 2 horizons (Figure 3). Grain-size analysis of aleurite-sand deposit cross-sections showed that sedimentation was in coastal-marine facies influenced by hydrodynamic river delta conditions. In the modern Gulf of Finland, deposits of similar grain-size composition are spread locally, mainly on the coastal shallow zone of eastern 
Nevskaya Guba, in southern Luzhskaya Guba, and Narva Bay (Ryabchuk et al. 2009). No evidence was found of strong erosions nor the transfer and redeposition of sediments in the studied sections. The horizontal deposit stratification is the result of water-level changes in the shallow basin.

\section{Hypsometric location of artifacts $\begin{aligned} & \text { Height above } \\ & \text { Sea level }(\mathrm{cm}) \quad \text { Lithological characteristics }\end{aligned}$}

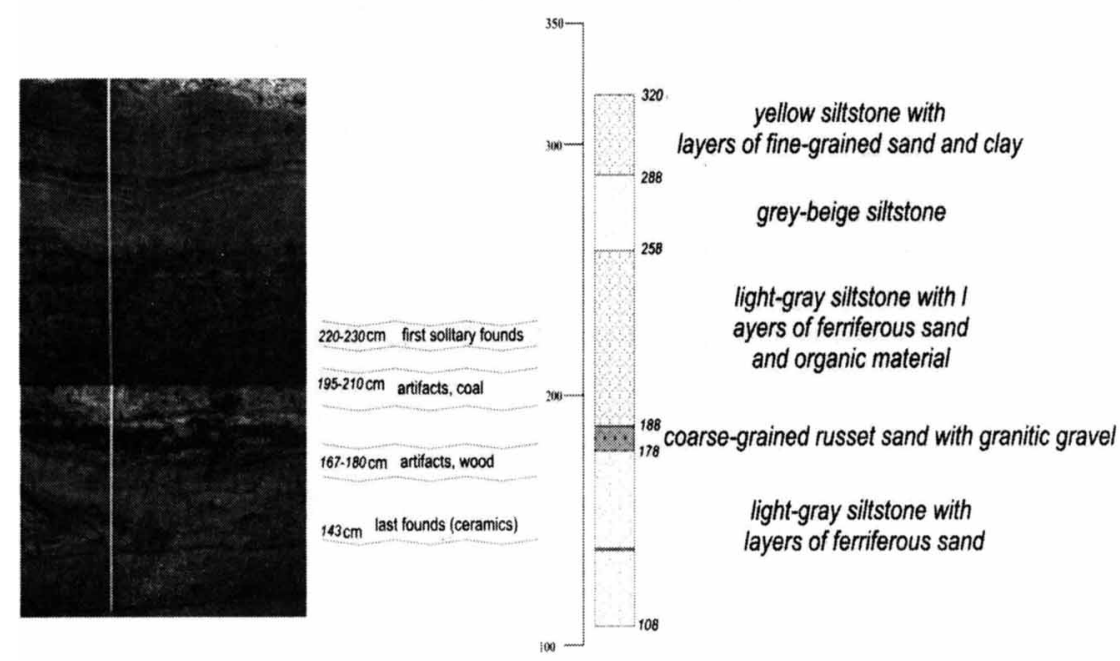

Figure 3 Cultural and lithological layers of Okhta 1 archaeological site

At the bottom of the cultural layer, remains of wood constructions and Neolithic ceramics were found. This layer is composed of gray-beige aleurite with light and brick-red sandy layers, and occurs from 1.6 to 1.3 to $1.2 \mathrm{~m}$ until $0.7-0.44 \mathrm{~m}$ on the Baltic altitude scale. The results of hypsometric marks show that the ancient surface was slightly inclined to the west. Therefore, cultural layers are located on different hypsometric levels. Regarding excavation $7 / 2$, for which the stratigraphy was considered in detail (Figure 3), the lowest ceramic fragments were discovered at $1.43 \mathrm{~m}$ asl. The lack of clear facial changes indicates the hydrodynamic conditions characteristic of a shallow coastal zone. The lower cultural layer is separated from the upper cultural layer by an interlayer of middle- and coarse-grained sand from 2.00 to $1.40 \mathrm{~m}$ in different parts of the cape. At $2.30-2.40 \mathrm{~m}$, lenses of coarse-grained sand were observed. In this interlayer and lenses, numerous Neolithic-Early Metal artifacts were found. The thickest layer of coarse-grained sand $(0.3-0.4 \mathrm{~m})$ was observed in the central part of the site and extended to the western part of the site, where artifacts were no longer found. This border likely was a coastal zone where the alluvial sand accumulated and formed the sand spits. Analogous forms can be observed on the modern Gulf of Finland coast in the Bolshaya Izhora district (Leontyev et al. 2010). The upper cultural layer, from 2.90 to $3.20 \mathrm{~m}$, consists of light-gray aleurite with interlayers of sand. In this layer, the remains of ancient inhabited structures and burials, fireplaces, different anthropogenic pits, ceramics, and flint complexes of the Late Neolithic-Early Metal ages were found.

Our investigations of sediments from cultural layers (Kulkova et al. 2010) allowed to us to conclude that the cultural layers were formed in subaerial conditions (i.e. a beach) and are separated by sediments that have formed during water-level increases in the shallow bay during transgressive phases. This argument is supported by the several levels of distribution of artifacts throughout the excavated zone. The formation of deposits and their related material culture remains were in situ during pro- 
cesses of sedimentation. We note some traces of sediment erosion resulting from water-level increases, which are marked in the distribution area.

The relief features and the distribution of prehistoric constructions and finds showed that at first the coastal sea zone was used by the ancient inhabitants for fishing. Later, the coastal zone and the river channels were occupied for living and fishing continued. The timing of cultural layer formation and the different types of archaeological complexes are supported by series of ${ }^{14} \mathrm{C}$ dates from different labs for various organic materials (wood, charcoal, humid acids, and food crust on ceramic walls; Figures 4, 5, 6 and Appendix). Conventional dates were obtained at the Herzen State Pedagogical University (lab code SPb) and Institute for the History of Material Culture RAS (lab code Le). Two ${ }^{14} \mathrm{C}$ AMS dates (Kulkova et al. 2010) were obtained from the Finnish Museum of Natural History Dating Lab (lab code Hela). Dates were calibrated using the OxCal v 3.10 program (Bronk Ramsey $1995,2001)$ and IntCal04 calibration curve (Reimer et al. 2004) and given in cal BC $(2 \sigma)$.

Yellow siltstone (3,10-3,40 m), Iron Age artifacts

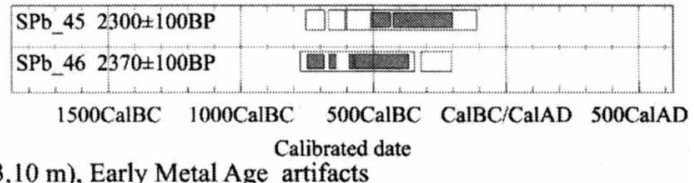

Gray-beige siltstone (2,80-3,10 m), Early Metal Age artifacts

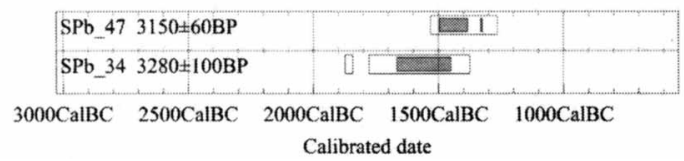

Figure 4 Calibrated ${ }^{14} \mathrm{C}$ dates of Early Metal Age and Iron Age organic artifacts
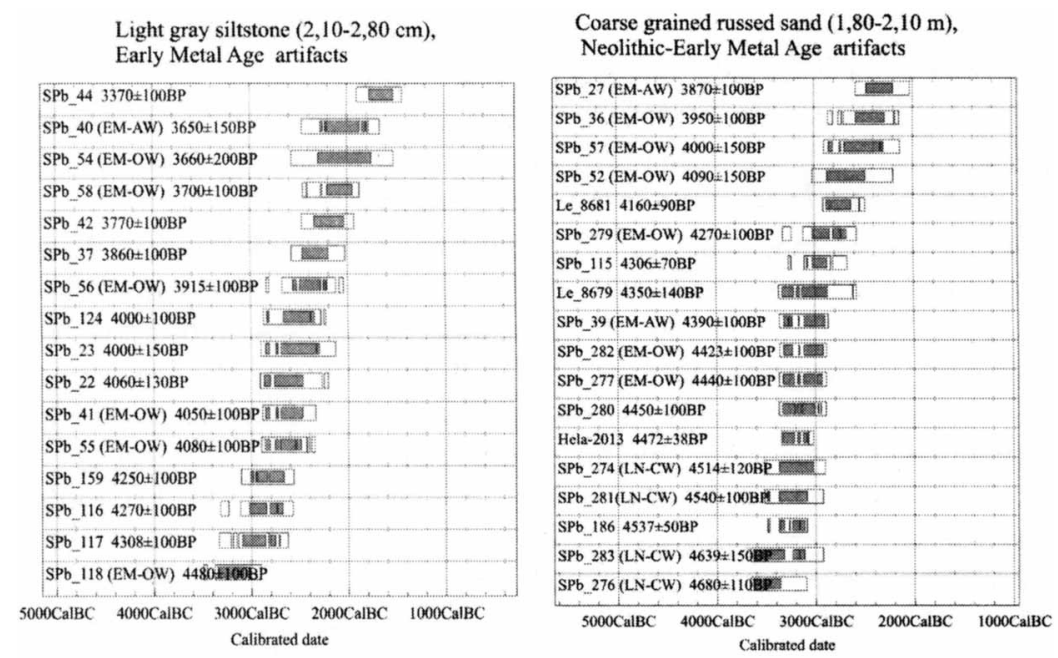

Figure 5 Calibrated ${ }^{14} \mathrm{C}$ dates of Neolithic-Early Metal Age organic artifacts: LN-CW Late Neolithic Comb ware; EM-OW - Early Metal organic-tempered ware; EM-AW - Early Metal asbestos-tempered ware.

To establish the chronology of cultural-historical processes, it was important to determine the sequences of wood constructions connected with fishing and economic activity in different parts of 


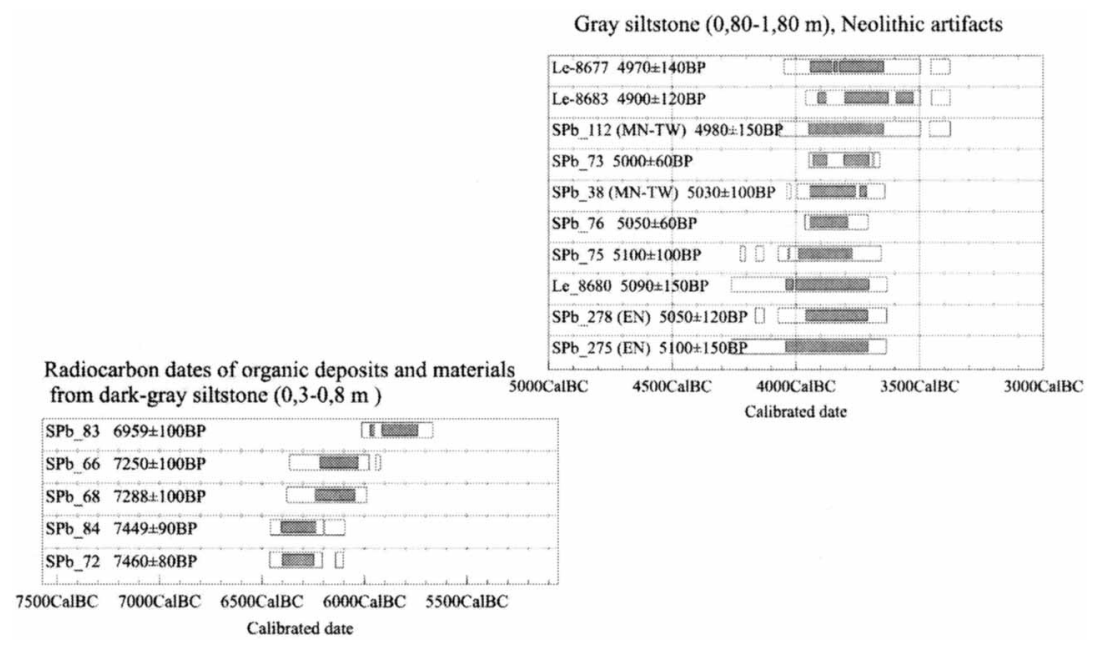

Figure 6 Calibrated ${ }^{14} \mathrm{C}$ dates of organic materials and Neolithic organic artifacts: $\mathrm{EN}$ - Early Neolithic Ware; MN-TW - Middle Neolithic Typical Comb ware.

the site. About 400 wood piles, of between 0.5 to $2.5 \mathrm{~m}$ length and 7 to $16 \mathrm{~cm}$ diameter, were excavated. The poles had planed lathes, some of which reached 4-5 m length. Coniferous and broad-leaf types of trees such as pine, spruce, alder, juniper, birch, willow, and rowan-tree were used. The wood piles were treated by stone tools.

The ${ }^{14} \mathrm{C}$ dates obtained for rings of 10 wood pile samples were used for synchronization with the calendar scale. For determining the age of individual trees, the wiggle-matching method was applied. On the basis of ${ }^{14} \mathrm{C}$ dating of sequences from 10 rings and $15-20$ rings for trees with small numbers of rings, the calendar age of trees was determined (Figure 7). The ${ }^{14} \mathrm{C}$ age of rings was calibrated with OxCal v 3.10 by using the statistic parameter $\chi_{n-1}^{2}$, where $n$ is the amount of annual tree rings (Bronk Ramsey 1995, 2001; Bronk Ramsey et al. 2001).

\section{RESULTS AND DISCUSSION}

${ }^{14} \mathrm{C}$ dating of artifacts and organic materials from cultural and lithological layers, the wiggle-matching method, and complex analyses of sediments and artifacts allow determination of the main paleoenvironmental events and the chronology of prehistoric occupations during the Neolithic-Metal ages in the studied region. Sediment accumulation in the shallow sea bay was connected with the periodic increase and decrease of the water level. A rhythm of sedimentation displaying a horizontal cleavage was conditioned by the water-level fluctuations. During 6459-5666 cal BC (Figure 6), the open, shallow, brackish bay extended to the mouth of the Okhta River. This bay formed part of the Littorina Sea. When the sea level decreased, however, the Okhta Bay became partly isolated from the Littorina Sea. Based on pollen analysis (Kulkova et al. 2010) in the deposits of this period, broad-leaf tree pollen was found, suggesting warm, humid climatic conditions of the Atlantic period.

The earliest ${ }^{14} \mathrm{C}$ dates obtained for charcoal and wood from the bottom cultural layer range from 4071 to $3633 \mathrm{cal}$ BC. This is likely the time when humans first populated this area, since the land emerged after the Littorina transgression, forming a sandy beach of the shallow bay. Prehistoric people of the Early-Middle Neolithic with Pit and Pit-Combed Ware ceramics used this territory primarily for fishing and hunting. At this time, the coniferous forest predominated as well as some broad- 

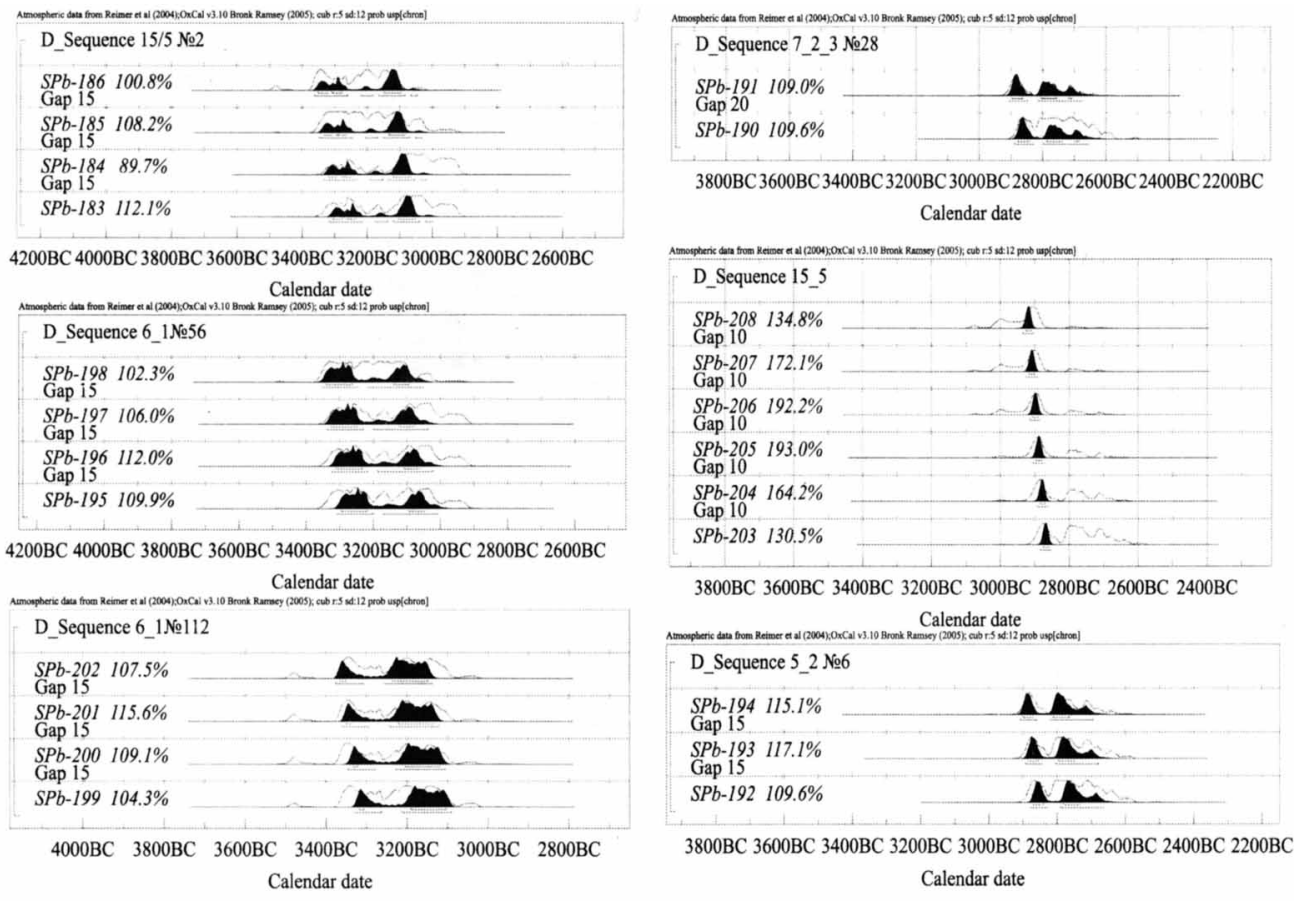

Figure 7 Plots of "wiggle matching" the wood pile samples

leaf trees (linden, elm, oak, beech, and maple). A warm and humid climate prevailed here; hazel and alder trees spread, as evidenced by hazelnuts found in the cultural layer of this period.)

Archaeological finds include fishing sinkers made from shale and elm and arrows from flint and shale, the stone abrasives. Ceramic fragments found in this cultural layer were comprised of clay with and an admixture of various crushed stones, feathers, and sand (Sorokin et al. 2009). The ceramics are decorated by pit and pit-combed ornamentation, while the ceramic food crust dates to 4260-3495 cal BC (Figure 8). The Typical Comb Ware ceramics (4036-3495 cal BC) have analogues with late complexes of Narva settlements, the Neolithic sites Akali and Kullamyagi in Estonia (Jaanits 1959; Gurina 1967), and with the ceramics types Ka 2:1 and Ka 2:2 from archaeological sites in Finland and southern Karelia (Europaeus-Äyräpää 1930; Pesonen 2004).

The typology of stone tools and the ornamentation and morphology of ceramic vessels indicate this cultural tradition as Early-Middle Neolithic. The ${ }^{14} \mathrm{C}$ results confirm the archaeological observations. The treated wood lathes date to 4071-3656, 3964-3708, and 3989-3633 cal BC. The lathes, piles, and numerous rails are typical of wood constructions used for fishing activity. Such constructions have analogues in the ethnographical reconstructions. They were used to partition off shallow rivers, lakes, and slow-flowing sea channels. Similar constructions of fish traps are found in some Neolithic sites on the coastal zone of the eastern Baltic Sea and in the forest zone of Russia. The closest resemblance to the artifacts from Okhta 1 site are the archaeological materials recovered in peat at the Sarnate site in modern Latvia (Vankina 1970; Dumpe et al. 2006).

The next distinct chronological period beginning $\sim 3500 \mathrm{BC}$ is characterized by climatic deterioration. The water level in the bay decreased and was replaced by a system of shallow streams. The mixed ${ }^{14} \mathrm{C}$ dates obtained from these layers (including the date $8750-8420$ cal BC, see Appendix) 


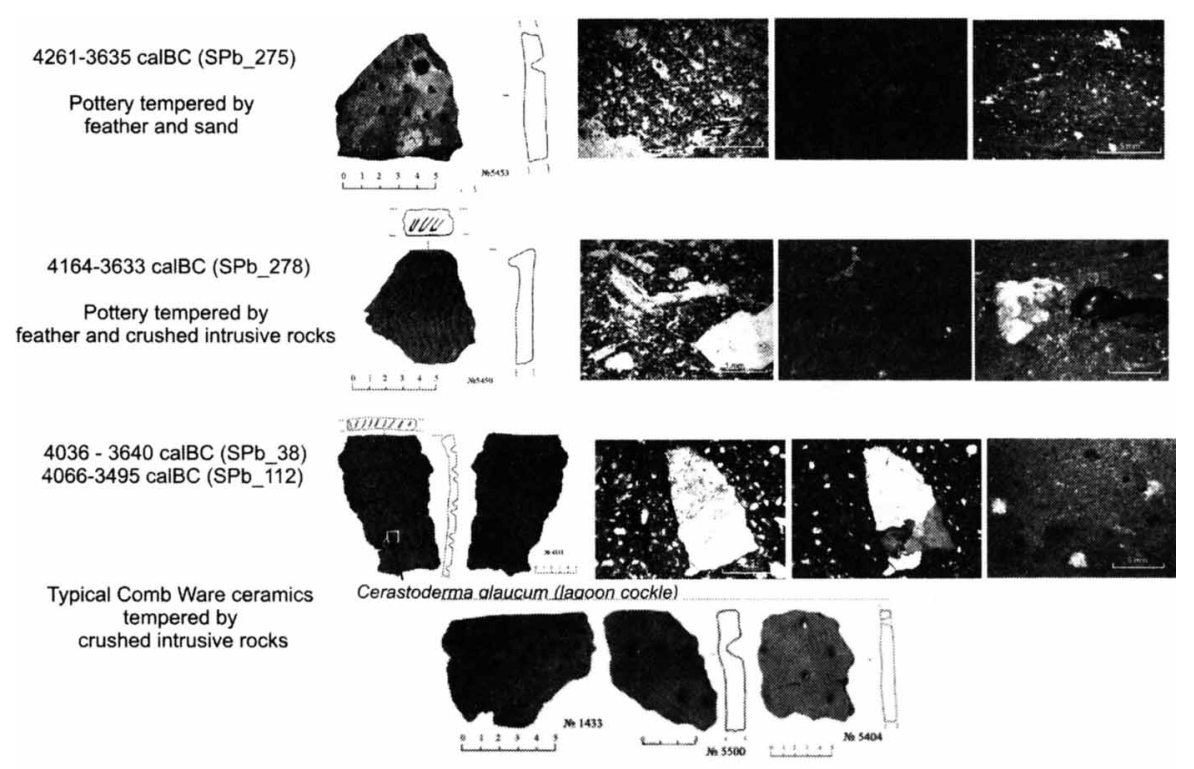

Figure 8 Petrography of Early-Middle Neolithic Ware (in non-polarizing and polarizing light and microphotography) and ${ }^{14} \mathrm{C}$ dates.

could be explained by the erosion of underlying deposits by river flows, by redeposition of light organic materials, and by sedimentation with the coarse-grained alluvial deposits. The results of wiggle-matching the wood piles allowed us to establish the sequence of wood constructions in different parts of the cape from 3600-2700 cal BC. The earliest wood constructions were found in the northwestern part of the cape (Figure 9), 3660-3590 cal BC. In the central and southwestern parts of the cape, most wood piles date to $3390-3000$ cal BC. The differences in distribution of wood piles in different parts of the cape could characterize changes in the shoreline (Figure 9).

The Late Neolithic ceramics of Okhta 1 comprise 2 types: 1) ceramics tempered by feather and sand with comb ornamentation, pits, and imprints of plants (3663-2905 cal BC; Figure 10); 2) ceramics tempered by feather and down with pit ornamentation. The latter type are similar to ceramics found at Uskela, Ka 3 in Finland (Pesonen 2004). While the ceramics with mineral admixtures ornamented by big, round-rhombic pits are similar to those found in eastern Karelia (Zhulnikov 1999; Vitenkova 2002).

The landscape and climatic conditions changed at 3200-3000 BC and ancient humans occupied this territory more extensively. The shallow basin coast sometimes turned to swamp, and birch became more widespread. The climate was warm and humid, and settlements and burials of the Late Neolithic-Early Metal Age appeared. Charcoals from this cultural layer were ${ }^{14} \mathrm{C}$ dated to 2700 2191, 2475-2189, 3400-2550, 2872-2280, and 2920-2480 cal BC. The cultural layer was formed for period from 3200 to 2200 cal BC. Artifacts and constructions for fishing and hunting, the remains of large houses with organic material and nearby artifacts, and stone tool work areas were found in this cultural layer. Analogues to the fishing trap constructions exist in the Yli-li Purkajasuo site in North Ostrobothnia, Finland (Zetterberg and Kinnunen 2009; Koivisto 2011). Two burials were excavated, with material cultural finds include bone remains and amber adornments (Sorokin et al. 2009). Charcoal from one of the burials was dated to $3345-2550$ cal BC. 


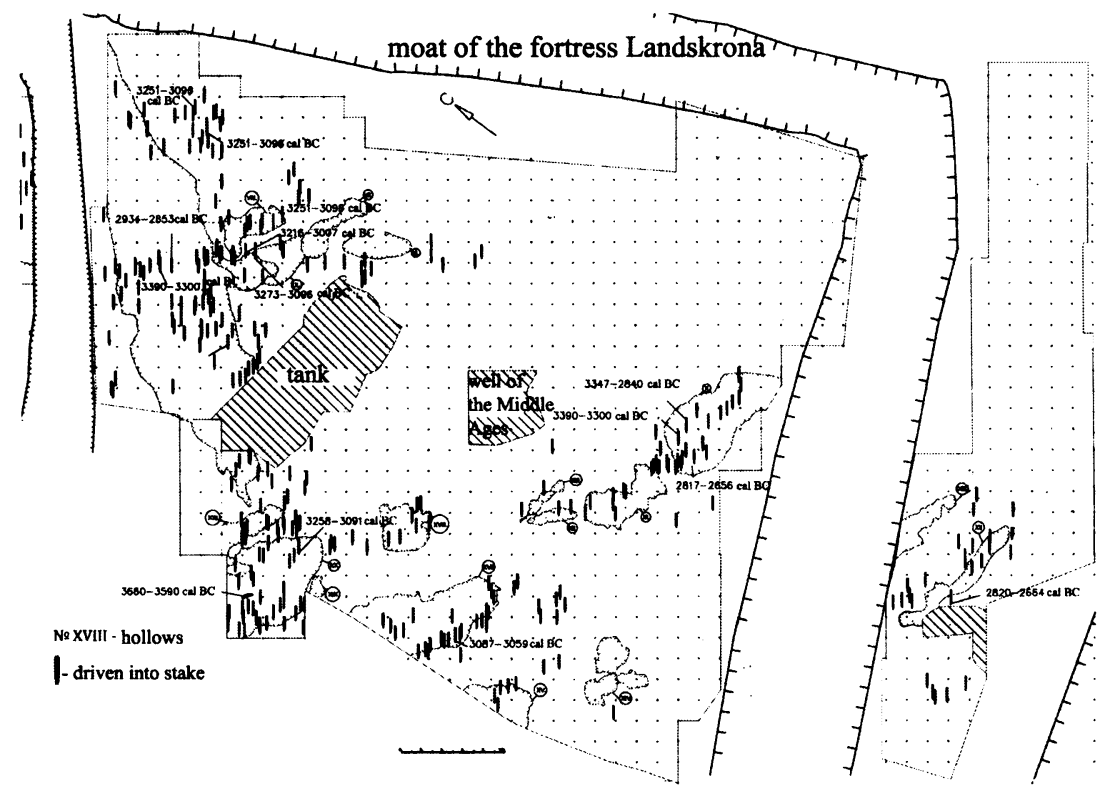

Figure 9 Distribution of wood pile constructions on the cape

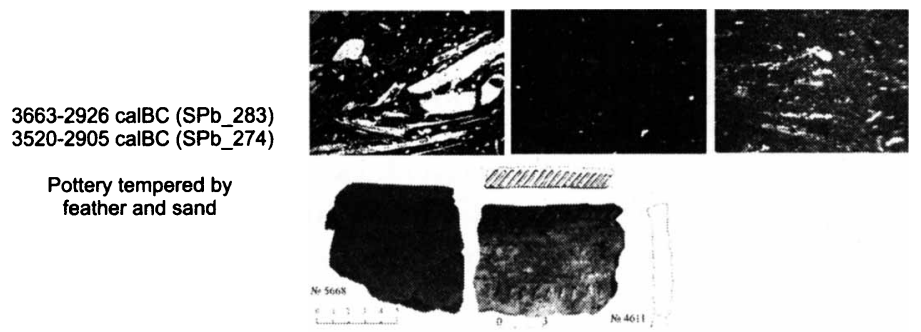

Figure 10 Petrography of Late Neolithic Ware (in non-polarizing and polarizing light and microphotography) and ${ }^{14} \mathrm{C}$ dates.

The ceramic assemblages from this cultural horizon exhibit changes in technology. The first group consists of pottery from clay tempered by crushed metamorphic rocks with asbestos (Figure 11). The vessels have some closed or straight forms with diameters of $30-50 \mathrm{~cm}$. The corolla vessels are straight, concaved inward or thickened forms. There are 3 or more ornamental styles for this group of ceramics. The corolla vessels were decorated with comb ornamentation or superficial pit impressions and dense rows of vast comb stamps in a triangular shape. The ${ }^{14} \mathrm{C}$ date of food crust from vessel surface with asbestos admixture is $3364-2871 \mathrm{cal} \mathrm{BC}$. This pot sherd has ornamentation with close rows of vast comb stamp composing narrow triangles, a decoration common for vessels of the "Voinavolok XVII" type in Karelia (Zhulnikov 1999). Another style of ornamentation is comb stamp or pits similar to the Kierikki/Polja ceramics from Finland (Pesonen 2004). The third style of ornament is horizontal or vertical zigzag with comb stamp, incisions, and pits. Some pots have flat ornamented bottoms, which have analogues with ceramics from Orovnavolok XVI in Karelia (Zhulnikov 1999). The technological features and different methods of decoration of asbestos-tempered ceramics are evidence of cultural heterogeneity. ${ }^{14} \mathrm{C}$ dates on food crust for asbestos-tempered ceramics range from 3376 to $2408 \mathrm{cal} \mathrm{BC}$. Similar ${ }^{14} \mathrm{C}$ dates were obtained for asbestos-tempered ceramics from archaeological sites in Finland and Karelia (Pesonen 2004; Zhulnikov 2005). 


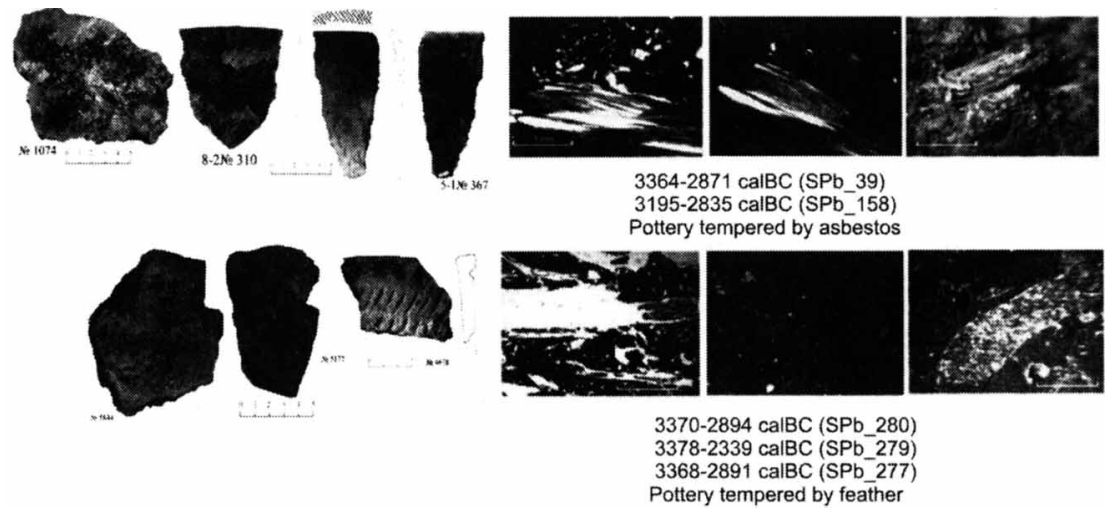

Figure 11 Petrography and ${ }^{14} \mathrm{C}$ dates of pottery tempered by asbestos and feather

Porous ceramics tempered by organic material, namely feathers and down (Figure 10), were made of thin smectite clay. The vessels are large, with diameters of $30-60 \mathrm{~cm}$. The pottery is decorated with superficial pit impressions. The corolla vessel is concaved inward and decorated with short incisions. The ${ }^{14} \mathrm{C}$ dates on food crust from the vessel surfaces are in the range 3370-2338 cal BC. Ceramics of this type are similar to collections from eastern Baltic, eastern Karelia, and Karelian Isthmus sites (Jaanits 1959; Zhulnikov 1999; Gerasimov et al. 2003). Ceramics tempered by organic and mineral materials with added shamotte or grog were found in the layers with organic-tempered wares.

Ceramics from the upper cultural layer (Figure 12) have ${ }^{14} \mathrm{C}$ dates from 3020 to $1524 \mathrm{cal} \mathrm{BC}$. They are made from clay tempered by organic or asbestos. Some of the sherds from this cultural layer have thick walls with net ornamentation, decorated by vast comb stamps on the textile. According to Kriiska et al. (2005), this ceramic type dates to 2900-2600 cal BC. Typological and morphological analyses of artifacts from this horizon correlates well with the relative and absolute chronology.
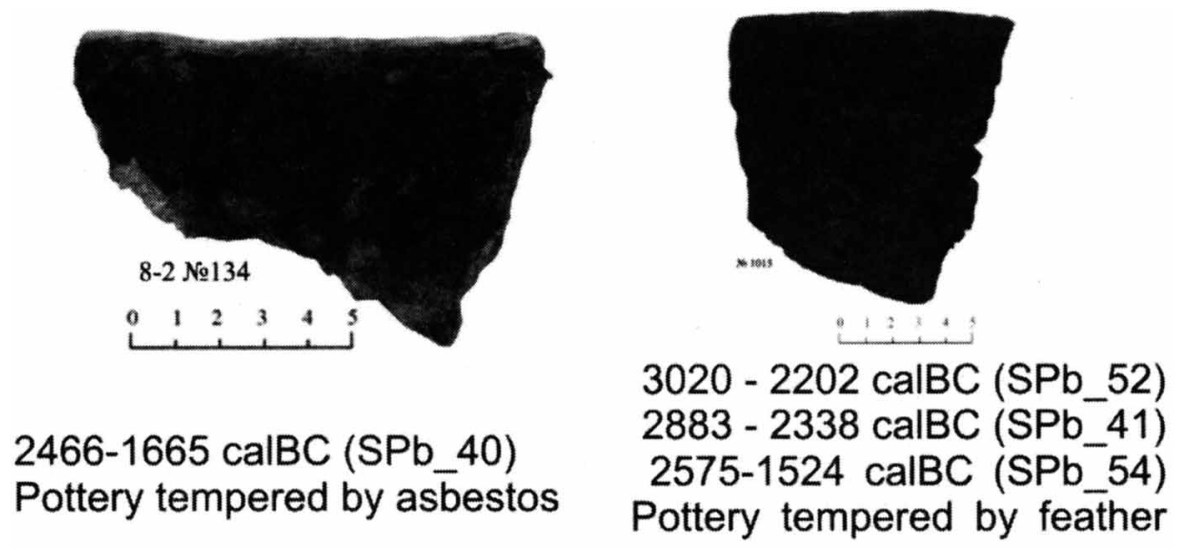

Figure 12 Pottery tempered by asbestos and feather and their ${ }^{14} \mathrm{C}$ dates

Most of the wood piles from this cultural layer were found in the deposits of the ancient river. The rive was 12 to $14 \mathrm{~m}$ wide and crossed the cape at its center. At the bottom of the river, spruce with numerous cones were found. The wood pile constructions associated with the river basin were in use a long time. Artifacts found in the river deposits date to the Neolithic-Early Metal Age, and include 
a bark box, ceramic sherds, and birch bark fishing weights. On the river bank, excavations uncovered a fireplace with burned stones and wood, burnt fish and animal bones, ceramic sherds, and stone tools. The ${ }^{14} \mathrm{C}$ dates obtained from these objects point to occupation from 3116 to 2574 cal BC.

The next lithological horizon was formed when the river delta flowed into the shallow sea bay. Charcoal particles in this horizon were ${ }^{14} \mathrm{C}$ dated to $1639-1128$ and $3350-3020 \mathrm{cal} \mathrm{BC}$. The latter sample was likely redeposited from a bottom layer. At $\sim 1500 \mathrm{BC}$, the paleogeographical situation changed and climatic conditions became unstable. The river flowed into the shallow sea bay, likely creating the Neva River Delta at this time. Saarnisto and Grönlund (1996) argue that the Neva Delta formed around $1350 \mathrm{BC}$. At this time, the majority of sand-siltstone deposits flowed into the Gulf of Finland. The delta region increased for $300 \mathrm{yr}$.

The next stage of occupation in this area was in the Iron Age, with the introduction of farming and agriculture. Birch and alder began spreading in the forest at this time. The open landscape also increased and humid meadows appeared. The distribution of cultural cereals with weeds, usually buckwheat, characterizes the extension of agricultural activity. Charcoal finds within the above bedding layer dated to 776-346 and 611-111 cal BC. Meanwhile, artifacts from the Iron Age and the Roman period (1000 cal BC to cal AD 1000) were also discovered.

\section{CONCLUSION}

Okhta Cape was an important site for connections and interactions between different cultural groups. The main chronological stages for this territory were reconstructed, beginning with the period from 6459 to $5666 \mathrm{cal} \mathrm{BC}$ during the Littorina transgression maximum. In this stage, the area at the mouth of Okhta and Neva rivers was covered by water. It was a shallow, low-salinity bay of the Littorina Sea with open contact to the sea. A decrease in the Littorina Sea level then caused the bay to become partly isolated and its coastal zone turned swampy. The appearance of the first humans in this territory can be dated to $4200 \mathrm{cal} \mathrm{BC}$, as the regression of the Littorina Sea was registered. Prehistoric people occupied the coastal zone of the shallow bay. The cultural traditions of Pit Ware and Pit-Combed Ware ceramics of Late Neolithic were used in this area by hunter-fishers.

The next stage, beginning at $3500 \mathrm{cal} \mathrm{BC}$, is characterized by a deterioration of climatic conditions. The coast receded and a system of shallow water rivers and channels emerged. These shallow rivers and channels contributed to the development of wood construction and traps for fishing. The environment registered significant changes from 3200-3000 cal BC. The shallow water coastal basin was periodically swampy, and the climate warm and humid. The coastal zone in this period bears the traces of settlements with constructions indicative of extended trading and burials of the Late Neolithic-Early Metal Age. The resulting ceramic complex comprises asbestos ceramics, ceramics tempered by feather and down, and ceramics with chamotte or grog.

Beginning around $1500 \mathrm{cal} \mathrm{BC}$, climatic conditions became unstable. The widening Neva River Delta flowed into a sea gulf, and cultural traditions appear from the Iron Age and Roman period. Data obtained suggest that agricultural activity also developed in this period.

The results of complex archaeological and paleogeographical investigations using ${ }^{14} \mathrm{C}$ dating allow to us to characterize the cultural-chronological succession of complexes of Neolithic and Early Metal Age and to reconstruct the landscape-climatic conditions for studied region. It should be noted that environmental conditions in this territory include the unique and different geographical components. In prehistory, these conditions were favorable for trade activity, fishing, and hunting. The territory is well positioned geographically for trade and cultural interactions. People therefore 
began occupying this territory when the Littorina Sea retreated and the area has been inhabited almost continuously until the present.

\section{ACKNOWLEDGMENTS}

This study is supported by the Program of Ministry Education and Science of the Russian Federation, P1156 of 03.08.2010.14.B37.21.1897.

\section{REFERENCES}

Bader ON. 1972. O drevneishikh finno-ugrakh na Urale i drevnikh finnakh mezhdu Uralom I Baltikoi (Problemy arkheologii i drevnei istorii ugrov: Sbornik statei sovetskikh $i$ vengerskikh arkheologov) [On the most ancient Finno-Ugric people of Ural and ancient Finnish people between Ural and Baltic Sea (The problems of archaeology and prehistory of Ugric people: materials of Soviet and Hungarian archaeologists)]. Moscow: Institut arkheologii AN SSSR. p 10-31.

Bronk Ramsey C. 1995. Radiocarbon calibration and analysis of stratigraphy: the OxCal program. Radiocarbon 37(2):425-30.

Bronk Ramsey C. 2001. Development of the radiocarbon calibration program. Radiocarbon 43(2A):355-63.

Bronk Ramsey C, van der Plicht J, Weninger B. 2001. 'Wiggle-matching' radiocarbon dates. Radiocarbon 43(2A):381-9.

Carpelan C. 1979. Om asbetskeramikens historia i Fennoskandien. Finskt Museum 1978. Helsinki: Gummerus. p 5-25.

Dolukhanov PM, Shukurov AM, Arslanov KA, Subetto DA, Zaitseva GI, Djinoridze EN, Kuznetsov DD, Ludikova AV, Sapelko TV, Savelieva LA. 2007. Evolution of waterways and early human settlements in the eastern Baltic area: radiocarbon-based chronology. Radiocarbon 49(2):527-42.

Dumpe B, Brziš V, Stilborg O. 2006. A dialogue across the Baltic on Narva and Ertebølle pottery. In: Hartz S, Lütz F, Terberger T, editors. Early Pottery - Dialog, Origin and Social Context. International Workshop at Shlezwig, 20-21 October 2006. p 409-41.

Europaeus-Äyräpää A. 1930. Die Relative Chronologie der Steinzeitlichen Keramik in Finnland. I- II. Acta Archaeologica I. Fasc. 2 \& 3. Copenhagen.

Galibin VA, Timofeev VI. 1993. Novii podhod k razrabotke problem vijavlenija istochnikov kremnevogo sirja dlja kultur kamennogo veka Vostochnoi Pribaltiki [New approach to the study of the problem of identification of the sources of flint raw material for the Stone Age cultures of the eastern Baltic region. Arheologicheskie Vesti 2:13-9.

Gerasimov DV, Subetto DA. 2009. Istoriya Ladogskogo ozera v svete arheologicheskih dannih [The history of Ladoga Lake in light of archaeological data. Izvestiya Rossiiskogo Gosudarstvennogo universiteta im.A.I.Herzena 106:37-49.

Gerasimov DV, Lisitsin SN, Timofeev VI. 2003. Materi- ali k arheologicheskoi karte Karelskogo peresheika (Leningradskaya oblast') (Pamjatniki kamennogo veka I perioda rannego metalla) [Materials and archaeological map of Karelian Ithmus (Leningradskaya district) (The monuments of Stone Age and period of Early Metal]. Saint Petersburg: IHMC RSA. p 3-63.

Gurina NN. 1967. Iz istorii drevnikh plemen zapadnykh oblastei SSSR (po materialam narvskoi ekspeditsii) [From History of Ancient Tribes of Western districts of USSR (On the materials of Expedition)]. Leningrad. Nauka. $144 \mathrm{p}$.

Huurre M. 2000. 9000 vuotta Suomen esihistoriaa. Otava. Helsinki: University of Helsinki Press.

Huurre M. 2003. Viipurin läänin kivikausi. Karjalan synty: Viipurin läänin historia. Jyväskylä, Gummerus 1:151-244.

Jaanits LY. 1959. Poselenia epohi neolita i rannego metalla $v$ priustie r.Emaiigi (Estonskaya SSR) [The sites of Neolithic and Early Metal Age in estuary of Emaiiga River (Estonian SSR)]. Tallin.

Koivisto S. 2011. Prehistoric wetland archaeology in Finland: sites and settlement in a changing environment. In: Pranckenaite E, editor. Wetland Settlements of the Baltic: A Prehistoric Perspective. Vilnius: Society of Lithuanian Archaeology. p 31-53.

Kriiska A, Tvauri A. 2007. Viron esihistoria. Helsinki: University of Helsinki Press.

Kriiska A, Lavento M, Peets J. 2005. New AMS dates of the Neolithic and Bronze age ceramics in Estonia: preliminary results and interpretations. Estonian Journal of Archeology 9(1):3-31.

Kulkova MA, Sapelko TV, Ludikova AV, Kuznetsov DA, Subetto DA, Nesterov EM, Gusentsova TM, Sorokin PE. 2010. Paleogepgrafiya i arheologia stojanok neolita-rannego metalla $v$ ustie reki Ohti (g.Sank-Peterburg) [Paleogeography and archaeology of NeolithicMetal Age sites at the Mouth of Okhta River (St. Petersburg) Izvestija Rossiiskogo Geograficheskogo obshestva 142(6):13-31.

Lang V, Kriiska A. 2001. Eesti esiajaloo periodiseering ja kronoloogia. Eesti Arheoloogia Ajakiri 5(2):83-109.

Lavento M. 2001. Textile ceramics in Finland and on the Karelian Isthmus. Nine variations and fugue on a theme of C. F. Meinander. Suomen Muinaismuistoyhdistyksen Aikakauskirja 109. Helsinki.

Lavento M, Halinen P, Timofeev V, Gerasimov D, Saksa 
A. 2002. An archaeological field survey of Stone Age and Early Metal period settlement at Kaukola (Sevastjanovo) and Räisälä (Melnikovo) in Karelian Isthmus in 1999. Fennoscandia Archaeologica 18:3-25.

Leontyev I, Ryabchuk D, Zhamoida V, Spiridonov M, Kurennoy D. 2010. Reconstruction of Late Holocene development of the submarine terrace in the eastern Gulf of Finland. Baltica 23(2):101-8.

Loze I. 1985. Ob osnovnih centrah obrabotki I putjah rasprostranenija vostochnobaltiiskogo jantarja $v$ period srednego neolita (Novoe $v$ arheologii Pribaltiki I sosednih territorii) [On the main processing centers and the ways of distribution of the East Baltic amber during the middle Neolithic period]. Tallin. p 58-77.

Meinander CF.1982. Finny - chast naseleniya severovostoka Evropy (Finnougorskii sbornik: Antropologiya, arkheologiya, etnografiya) [Finns a part of heritage of northeastern Europe (Finn-Ugrian materials: Antropology, Archaeology, Ethnography)]. Moscow: Nauka. p 10-32.

Miettinen A. 2002. Relative Sea-Level Changes in the Eastern Part of the Gulf of Finland During the Last 8000 Years. Annual of the Academia Scientiarum Fennica Geologica-Geographica 162. Helsinki.

Ots M. 2003. Stone Age amber finds in Estonia. In: Amber in Archaeology. Proceedings of the Fourth International Conference on Amber in Archaeology, Talsi 2001. Riga. p 96-107.

Pesonen P. 1999. Radiocarbon dating of birch bark pitches in typical comb ware in Finland. In: Huurre M, editor. Dig it All. Papers Dedicated to Ari Siiriäinen. Helsinki: Finnish Antiquarian Society. p 191-7.

Pesonen P. 2004. Neolithic pots and ceramics chronology-AMS-datings of Middle and Late Neolithic ceramics in Finland. In Uino P, editor. Fenno-Ugri et Slavi 2002: Dating and Chronology. Museoviraston arkeologian osaston julkaisuja no 10. Helsinki: National Board of Antiquities. p 87-97.

Reimer PJ, Baillie MGL, Bard E, Bayliss A, Beck JW, Bertrand CJH, Blackwell PG, Buck CE, Burr GS, Cutler KB, Damon PE, Edwards RL, Fairbanks RG, Friedrich M, Guilderson TP, Hogg AG, Hughen KA, Kromer B, McCormac G, Manning S, Bronk Ramsey C, Reimer RW, Remmele S, Southon JR, Stuiver M, Talamo S, Taylor FW, van der Plicht J, Weyhenmeyer CE. 2004. IntCal04 terrestrial radiocarbon age calibration, 0-26 cal kyr BP. Radiocarbon 46(3):1029-58.

Rõuk A-M. 1995. Loodusolud hilisjääajast tänapäevani. Eesti talurahva ajalugu I:16-41.
Ryabchuk D, Sukhacheva L, Spiridonov M, Zhamoida V, Kurennoy D. 2009. Coastal processes in the Eastern Gulf of Finland - possible driving forces and connection with the near-shore zone development. Estonian Journal of Engineering 15(3):151-67.

Saarnisto M, Grönlund T. 1996. Shoreline displacement of Lake Ladoga - new data from Kilpolansaari. $\mathrm{Hy}$ drobiologia 322:205-15.

Saksa AI. 2001. Priladozhskaya Kareliya i oblast Savo s drevneishikh vremen i do XIVv. (Ocherki istoricheskoi geografii: Severozapad Rossii. Slaviane $i$ finny) [Karelia near Ladoga Lake and Savo district from prehistoric time to XIV c. (Essay of historical geography: North-Western Russia. Slavs and Finns)]. Saint Petersburg: Izd. SPb. Gos Univ. p 257-71.

Saksa AI. 2006. The Karelian Isthmus: origins of the natural and human environment. Archaeology, Ethnology \& Anthropology of Eurasia 2(26):35-44.

Sorokin PE, Gusentsova TM, Glukhov VO, Ekimova AA, Kulkova MA. 2009. Nekotorie rezultati izuchenija poselenija Ohta 1 v Sankt-Peterburge. Epoha neolita-rannego metalla [Some results of investigation of site Okhta 1 in St.Petersburg. Epoch of Neolithic-Early Metal Age] Arheologicheskoe nasledie Sankt-Peterburga 3:205-21.

Timofeev VI. 1985. Novie nahodki mezolita I rannego neolita $v$ Leningradskoi oblasti [New Mesolithic and early Neolithic finds in the Leningrad region]. Novoe $v$ arheologii severo-zapada Leningradskoi oblasti. p 11-5.

Vankina LV. 1970. Torfjanikovaja stojanka Sarnate [Site from bog Sarnate]. Riga: Zinatne.

Vitenkova IF. 2002. Pamjatniki pozdnego neolita na territorii Karelii [The Late Neolithic settlements on the territory of Karelia]. Petrozavodsk.

Zetterberg P, Kinnunen T. 2009. Yli-lin Purkajasuon puulöytöjen dendrokronologinen tutkimus. Muinaistutkija 1:11-21.

Zhulnikov AM. 1999. Eneolit Karelii [Eneolith of Karelia]. Petrozavodsk.

Zhulnikov AM. 2005. Poselenia epohi rannego metalla Yugo-Zapadnogo Pribelomoria [The sites of Early Metal Age of southern-western Pribelomorya]. Petrozavodsk.

Zhulnikov AM. 2008. Exchange of amber in northern Europe in the III Millennium BC as a factor of social interactions. Estonian Journal of Archaeology 12(1): 3-15. 
APPENDIX

${ }^{14} \mathrm{C}$ dates from the Okhta 1 site. ${ }^{\mathrm{a}}$

\begin{tabular}{|c|c|c|c|c|}
\hline Lab ID & ${ }^{14} \mathrm{C}$ date $\mathrm{BP}$ & Cal age $\mathrm{BC}(2 \sigma)$ & Material & Archaeological context \\
\hline Hela-2107 & $9321 \pm 61$ & $8744-8420$ & plant remains & excavation $7 / 2,188 \mathrm{~m}$ \\
\hline $\mathrm{SPb}-72$ & $7460 \pm 90$ & $6462-6104$ & humic acid & excavation $16-1$ \\
\hline $\mathrm{SPb}-84$ & $7449 \pm 90$ & $6459-6096$ & humic acid & excavation $16-1$, pit, $80 \mathrm{~m}$ \\
\hline $\mathrm{SPb}-68$ & $7288 \pm 85$ & $6380-5990$ & seaweed & excavation $16-1$, pit, $80 \mathrm{~m}$ \\
\hline $\mathrm{SPb}-66$ & $7250 \pm 100$ & $6365-5922$ & humic acid & excavation $16-1$, pit \\
\hline $\mathrm{SPb}-83$ & $6959 \pm 100$ & $6012-5666$ & humic acid & excavation $16-1$, pit \\
\hline $\mathrm{SPb}-275$ & $5100 \pm 150$ & $4261-3634$ & food crust & $\begin{array}{l}\text { excavation } 7 / 2 / 4 \text {, square } 5^{\prime} 13,140 \mathrm{~m} \text {, } \\
\text { no. } 5453\end{array}$ \\
\hline Le- 8680 & $5090 \pm 150$ & $4260-3632$ & charcoal & excavation $7 / 2$, square Ц’ 15,184 m \\
\hline $\mathrm{SPb}-75$ & $5100 \pm 100$ & $4224-3655$ & bark & excavation $16-1$, pit, $105 \mathrm{~m}$ \\
\hline $\mathrm{SPb}-278$ & $5050 \pm 120$ & $4164-3633$ & food crust & $\begin{array}{l}\text { excavation } 7 / 2 / 4 \text {, square } \Pi ' 14,157 \mathrm{~m} \text {, } \\
\text { no. } 5450\end{array}$ \\
\hline $\mathrm{SPb}-76$ & $5050 \pm 60$ & $3963-3708$ & wood & excavation 16 \\
\hline $\mathrm{SPb}-38$ & $5030 \pm 100$ & $4036-3640$ & food crust & excavation $7 / 2$, no. $1288,187 \mathrm{~m}$ \\
\hline $\mathrm{SPb}-73$ & $5000 \pm 60$ & $3946-3660$ & wood & excavation $16,70 \mathrm{~m}$ \\
\hline $\mathrm{SPb}-112$ & $4980 \pm 150$ & $4065-3375$ & food crust & excavation $7 / 2$, square Д’ $3,80 \mathrm{~m}$, pit 4111 \\
\hline Le- 8677 & $4970 \pm 140$ & $4047-3376$ & charcoal & excavation $7 / 2$, square $\Phi^{\prime} 17,211 \mathrm{~m}$ \\
\hline Le- 8683 & $4900 \pm 120$ & $3959-3376$ & charcoal & excavation $7 / 2$, square $H^{\prime} 17,203 \mathrm{~m}$ \\
\hline $\mathrm{SPb}-276$ & $4680 \pm 110$ & $3659-3095$ & food crust & $\begin{array}{l}\text { excavation } 7 / 2 \text {, square } A^{\prime} 8,124 \mathrm{~m} \text {, } \\
\text { no. } 5387\end{array}$ \\
\hline $\mathrm{SPb}-283$ & $4639 \pm 150$ & $3663-2926$ & food crust & $\begin{array}{l}\text { excavation } 7 / 2 \text {, square C' } 11,134 \mathrm{~m} \text {, } \\
\text { no. } 5568\end{array}$ \\
\hline $\mathrm{SPb}-281$ & $4540 \pm 100$ & $3518-2925$ & food crust & $\begin{array}{l}\text { excavation } 7 / 2 \text {, square } \Gamma^{\prime} 12,157 \mathrm{~m} \text {, } \\
\text { no. } 5308\end{array}$ \\
\hline $\mathrm{SPb}-186$ & $4537 \pm 50$ & $3488-3089$ & wood & pile $15 / 5$ no. $2,46-60$ inner tree rings \\
\hline $\mathrm{SPb}-185$ & $4482 \pm 50$ & $3359-3013$ & wood & pile $15 / 5$ no. $2,31-45$ tree rings \\
\hline $\mathrm{SPb}-184$ & $4417 \pm 50$ & $3330-2912$ & wood & pile $15 / 5$ no. $2,16-30$ tree rings \\
\hline $\mathrm{SPb}-183$ & $4433 \pm 50$ & $3334-2919$ & wood & pile $15 / 5$ no. $2,0-15$ outer tree rings \\
\hline $\mathrm{SPb}-198$ & $4503 \pm 50$ & $3361-3026$ & wood & pile $6 / 1$ no. $56,46-57$ inner tree rings \\
\hline $\mathrm{SPb}-197$ & $4443 \pm 50$ & $3335-2925$ & wood & pile $6 / 1$ no. $56,31-45$ tree rings \\
\hline $\mathrm{SPb}-196$ & $4447 \pm 50$ & $3338-2926$ & wood & pile $6 / 1$ no. $56,16-30$ tree rings \\
\hline $\mathrm{SPb}-195$ & $4454 \pm 50$ & $3340-2931$ & wood & pile $6 / 1$ no. $56,0-15$ outer tree rings \\
\hline $\mathrm{SPb}-202$ & $4543 \pm 50$ & $3492-3089$ & wood & pile $6 / 1$ no. $112,46-55$ inner tree rings \\
\hline $\mathrm{SPb}-201$ & $4531 \pm 50$ & $3369-3030$ & wood & pile $6 / 1$ no. $112,31-45$ tree rings \\
\hline $\mathrm{SPb}-200$ & $4547 \pm 50$ & 3494-3089 & wood & pile $6 / 1$ no. $112,16-30$ tree rings \\
\hline $\mathrm{SPb}-199$ & $4548 \pm 50$ & 3494-3089 & wood & pile $6 / 1$ no. $112,0-15$ outer tree rings \\
\hline $\mathrm{SPb}-274$ & $4510 \pm 120$ & $3519-2905$ & food crust & $\begin{array}{l}\text { excavation 7/2, square Д’9, } 168 \mathrm{~m} \text {, } \\
\text { no. } 4611\end{array}$ \\
\hline $\mathrm{SPb}-118$ & $4480 \pm 100$ & $3495-2903$ & food crust & excavation $5 / 1,240-232 \mathrm{~m}$ \\
\hline Hela-2013 & $4472 \pm 38$ & $3342-3023$ & charcoal & excavation $7 / 2,251 \mathrm{~m}$ \\
\hline $\mathrm{SPb}-280$ & $4450 \pm 100$ & $3369-2894$ & food crust & $\begin{array}{l}\text { excavation } 7 / 2 \text {, square } W^{\prime} 16,139-130 \mathrm{~m} \text {, } \\
\text { no. } 5844\end{array}$ \\
\hline $\mathrm{SPb}-277$ & $4440 \pm 100$ & $3368-2890$ & food crust & $\begin{array}{l}\text { excavation } 7 / 2 \text {, square } E^{\prime} 12,174 \mathrm{~m} \text {, } \\
\text { no. } 4678\end{array}$ \\
\hline $\mathrm{SPb}-282$ & $4423 \pm 100$ & $3363-2888$ & food crust & $\begin{array}{l}\text { excavation } 7 / 2 \text {, square } \text { ' }^{\prime} 8,154 \mathrm{~m} \text {, } \\
\text { no. } 5382-2\end{array}$ \\
\hline SPb-191 & $4232 \pm 50$ & $2920-2634$ & wood & pile $7 / 2 / 3$ no. $28,0-15$ inner tree rings \\
\hline
\end{tabular}


${ }^{14} \mathrm{C}$ dates from the Okhta 1 site. ${ }^{\mathrm{a}}$ (Continued)

\begin{tabular}{|c|c|c|c|c|}
\hline Lab ID & ${ }^{14} \mathrm{C}$ date $\mathrm{BP}$ & Cal age $\mathrm{BC}(2 \sigma)$ & Material & Archaeological context \\
\hline $\mathrm{SPb}-190$ & $4433 \pm 50$ & $3334-2919$ & wood & pile $7 / 2 / 3$ no. $28,16-30$ outer tree rings \\
\hline $\mathrm{SPb}-39$ & $4390 \pm 100$ & $3363-2870$ & food crust & excavation $7 / 2,1074$, square $P^{\prime} 7 ', 192 \mathrm{~m}$ \\
\hline Le-8679 & $4350 \pm 140$ & $3369-2580$ & charcoal & excavation $7 / 2$, square $\Pi^{\prime} 7,231 \mathrm{~m}$ \\
\hline $\mathrm{SPb}-208$ & $4300 \pm 50$ & $3087-2759$ & wood & pile $15 / 5$ no. $1,51-60$ inner tree rings \\
\hline $\mathrm{SPb}-207$ & $4290 \pm 50$ & $3083-2703$ & wood & pile $15 / 5$ no. $1,41-50$ tree rings \\
\hline $\mathrm{SPb}-206$ & $4278 \pm 50$ & $3025-2696$ & wood & pile $15 / 5$ no. $1,31-40$ tree rings \\
\hline $\mathrm{SPb}-205$ & $4257 \pm 50$ & $3011-2676$ & wood & pile $15 / 5$ no. $1,21-30$ tree rings \\
\hline $\mathrm{SPb}-204$ & $4241 \pm 50$ & $2928-2633$ & wood & pile $15 / 5$ no. $1,11-20$ tree rings \\
\hline $\mathrm{SPb}-203$ & $4210 \pm 50$ & $2908-2630$ & wood & pile $15 / 5$ no. $1,0-10$ outer tree rings \\
\hline $\mathrm{SPb}-115$ & $4306 \pm 70$ & $3264-2672$ & wood & $\begin{array}{l}\text { excavation } 15 / 1 \text {, square } Y^{\prime} 14,75 \mathrm{~m} \text {, fire- } \\
\text { place }\end{array}$ \\
\hline $\mathrm{SPb}-117$ & $4308 \pm 100$ & $3333-2625$ & wood & excavation $15 / 1$, square Ц’14, 89 m \\
\hline $\mathrm{SPb}-116$ & $4270 \pm 100$ & $3321-2574$ & wood & $\begin{array}{l}\text { excavation } 15 / 1 \text {, square } \mathrm{Y}^{\prime} 14,75 \mathrm{~m} \text {, fire- } \\
\text { place }\end{array}$ \\
\hline $\mathrm{SPb}-159$ & $4250 \pm 100$ & $3104-2565$ & wood & $\begin{array}{l}\text { excavation } 15 / 1 \text {, square } И^{\prime} 15,124- \\
139 \mathrm{~m}\end{array}$ \\
\hline SPb-194 & $4178 \pm 50$ & 2893-2619 & wood & pile $15 / 2$ no. $6,31-45$ inner tree rings \\
\hline $\mathrm{SPb}-193$ & $4196 \pm 50$ & $2900-2629$ & wood & pile $15 / 2$ no. $6,16-30$ tree rings \\
\hline SPb-192 & $4178 \pm 50$ & $2893-2619$ & wood & pile $15 / 2$ no. $6,0-15$ outer tree rings \\
\hline $\mathrm{SPb}-279$ & $4270 \pm 100$ & $3321-2574$ & food crust & excavation $7 / 2$ \\
\hline Le- 8681 & $4160 \pm 90$ & $2912-2487$ & charcoal & excavation $7 / 2$, square $H^{\prime} 17,253 \mathrm{~m}$ \\
\hline $\mathrm{SPb}-52$ & $4090 \pm 150$ & $3020-2202$ & food crust & excavation $7 / 1,207 \mathrm{~m}$, no. 1003 \\
\hline $\mathrm{SPb}-55$ & $4080 \pm 200$ & $2895-2347$ & food crust & $\begin{array}{l}\text { excavation } 8 / 2 \text {, square } \Pi^{\prime} 46^{\prime}, 278 \mathrm{~m} \text {, } \\
\text { no. } 190\end{array}$ \\
\hline $\mathrm{SPb}-41$ & $4050 \pm 100$ & $2883-2338$ & food crust & excavation $7 / 2$, square $\mathrm{P}^{\prime} 4^{\prime}, 209 \mathrm{~m}$ \\
\hline $\mathrm{SPb}-22$ & $4060 \pm 130$ & $2908-2275$ & charcoal & excavation $7 / 2$, square $0^{\prime} 1{ }^{\prime}, 207 \mathrm{~m}$ \\
\hline $\mathrm{SPb}-57$ & $4000 \pm 150$ & $2900-2132$ & food crust & $\begin{array}{l}\text { excavation } 7 / 2 \text {, no. } 1020 \text {, square } O^{\prime} 3 \text {, } \\
203 \mathrm{~m}\end{array}$ \\
\hline $\mathrm{SPb}-23$ & $4000 \pm 100$ & $2872-2280$ & charcoal & excavation 7/2,кв П'1',233 m \\
\hline $\mathrm{SPb}-124$ & $4000 \pm 150$ & $2901-2133$ & charcoal & excavation $15 / 1$, square $5 / 6^{\prime}, 250 \mathrm{~m}$ \\
\hline $\mathrm{SPb}-36$ & $3950 \pm 100$ & $2858-2141$ & food crust & $\begin{array}{l}\text { excavation } 7 / 2 \text {, no. } 1015 \text {, square } O^{\prime} 5 \text { ', } \\
216 \mathrm{~m}\end{array}$ \\
\hline $\mathrm{SPb}-56$ & $3915 \pm 100$ & $2675-2127$ & food crust & $\begin{array}{l}\text { excavation } 8 / 2 \text {, square } \Pi^{\prime} 42^{\prime}, 269 \mathrm{~m} \text {, } \\
\text { no. } 149\end{array}$ \\
\hline $\mathrm{SPb}-27$ & $3870 \pm 100$ & $2580-2031$ & food crust & excavation $7 / 2,1218$, square $P^{\prime} 11^{\prime}, 218 \mathrm{~m}$ \\
\hline $\mathrm{SPb}-37$ & $3860 \pm 60$ & $2475-2189$ & charcoal & excavation $7 / 2,218 \mathrm{~m}$ \\
\hline $\mathrm{SPb}-42$ & $3770 \pm 100$ & $2471-1934$ & charcoal & excavation $7 / 2$, square $H^{\prime} 4^{\prime}, 213 \mathrm{~m}$ \\
\hline $\mathrm{SPb}-58$ & $3700 \pm 100$ & $2408-1876$ & food crust & excavation $7 / 2$ \\
\hline $\mathrm{SPb}-54$ & $3660 \pm 200$ & $2575-1524$ & food crust & $\begin{array}{l}\text { excavation } 8 / 2 \text {, square } \Pi^{\prime} 42^{\prime}, 303 \mathrm{~m} \text {, } \\
\text { no. } 114\end{array}$ \\
\hline $\mathrm{SPb}-40$ & $3650 \pm 150$ & $2466-1665$ & food crust & $\begin{array}{l}\text { excavation } 8 / 2 \text {, square } \text { U’ }^{\prime} 41^{\prime}, 293 \mathrm{~m} \text {, } \\
\text { no. } 134\end{array}$ \\
\hline $\mathrm{SPb}-44$ & $3370 \pm 100$ & $1901-1439$ & charcoal & excavation $7 / 2$, square $\Gamma^{\prime} 5^{\prime}, 249 \mathrm{~m}$ \\
\hline $\mathrm{SPb}-34$ & $3280 \pm 150$ & 1949-1194 & charcoal & excavation $7 / 2,220 \mathrm{~m}$ \\
\hline $\mathrm{SPb}-47$ & $3150 \pm 100$ & $1639-1128$ & charcoal & excavation $7 / 1$, square Д’'13', $260 \mathrm{~m}$ \\
\hline $\mathrm{SPb}-46$ & $2370 \pm 100$ & $776-346$ & charcoal & excavation $7 / 1$, square $Ж^{\prime} 19^{\prime}, 325 \mathrm{~m}$ \\
\hline $\mathrm{SPb}-45$ & $2300 \pm 100$ & $601-111$ & charcoal & excavation $7 / 1$, square $5^{\prime} 15^{\prime}, 340 \mathrm{~m}$ \\
\hline
\end{tabular}

${ }^{a} \delta^{13} \mathrm{C}$ values were determined at the AMS Dating Laboratory of Finnish Museum of Natural History: -30.3\%o (Hela-2107); $-27.0 \%$ (Hela-2013). In the conventional dating labs of $\mathrm{SPb}$ and $\mathrm{Le}, \delta^{13} \mathrm{C}$ values of $-25.0 \%$ were used. 